\title{
Strategies to Suppress Hydrogen-Consuming Microorganisms Affect Macro and Micro Scale Structure and Microbiology of Granular Sludge
}

\author{
A.A. Abreu, J.I. Alves, M.A. Pereira, D.Z. Sousa, M.M. Alves \\ IBB-Institute for Biotechnology and Bioengineering, Centre of Biological Engineering, \\ University of Minho, 4710-057 Braga, Portugal; telephone: +351-253-604-400; \\ fax: +351-253-678-986; e-mail: angela_abreu@deb.uminho.pt
}

Received 15 November 2010; revision received 10 February 2011; accepted 18 March 2011

Published online 28 March 2011 in Wiley Online Library (wileyonlinelibrary.com). DOI 10.1002/bit.23145

ABSTRACT: Treatment of anaerobic granules with heat and two chemical treatments, contacting with 2-bromoethanesulfonate (BES) and with BES + Chloroform, were applied to suppress hydrogen-consuming microorganisms. Three mesophilic expanded granular sludge bed (EGSB) reactors - $\mathrm{R}_{\text {Heat }}, \mathrm{R}_{\mathrm{BES}}$, and $\mathrm{R}_{\mathrm{BES}}+$ Chlo - were inoculated with the treated sludges and fed with synthetic sugar-based wastewater $\left(5 \mathrm{~g}_{\mathrm{COD}} \mathrm{L}^{-1}\right.$, HRT $\left.20-12 \mathrm{~h}\right)$. Morphological integrity of granules and bacterial communities were assessed by quantitative image analysis and 16S rRNA gene based techniques, respectively. Hydrogen production in $\mathrm{R}_{\text {Heat }}$ was under $300 \mathrm{~mL} \mathrm{H}_{2} \mathrm{~L}^{-1}$ day $^{-1}$, with a transient peak of $1,000 \mathrm{~mL} \mathrm{H}_{2} \mathrm{~L}^{-1}$ day $^{-1}$ after decreasing HRT.

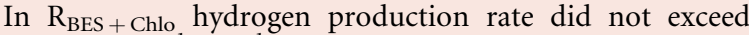
$300 \mathrm{~mL} \mathrm{H}_{2} \mathrm{~L}^{-1}$ day $^{-1}$ and there was granule fragmentation, release of free filaments from aggregates, and decrease of granule density. In $\mathrm{R}_{\mathrm{BES}}$, there was an initial period with unstable hydrogen production, but a pulse of BES triggered its production rate to $700 \pm 200 \mathrm{~mL} \mathrm{H}_{2} \mathrm{~L}^{-1} \mathrm{day}^{-1}$. This strategy did not affect granules structure significantly. Bacteria branching within Clostridiaceae and Ruminococcaceae were present in this sludge. This work demonstrates that, methods applied to suppress $\mathrm{H}_{2}$-consuming microorganisms can cause changes in the macro- and microstructure of granular sludge, which can be incompatible with the operation of high-rate reactors.

Biotechnol. Bioeng. 2011;108: 1766-1775.

(C) 2011 Wiley Periodicals, Inc.

KEYWORDS: biohydrogen; dark fermentation; image analysis; bacterial communities; EGSB reactors

Correspondence to: A.A. Abreu

Contract grant sponsor: Fundação para a Ciência e Tecnologia (FCT) and European Community fund FEDER

Contract grant number: FCOMP-01-0124-FEDER-007087; PTDC/BI0/69745/2006; SFRH/ BD/29823/2006; SFRH/BD/48965/2008

\section{Introduction}

Hydrogen can be continuously generated from renewable organic materials in mixed culture dark fermentation processes. These processes offer several advantages over pure culture fermentations, namely no need for media sterilization, robustness, and increased adaptation capacity offered by the microbial consortia, possibility of mixed substrates co-fermentation, and better suitability for continuous processing (Kleerebezem and van Loosdrecht, 2007; Temudo et al., 2007). However, in anaerobic mixed culture systems, hydrogen produced by fermentative bacteria such as Clostridium or Enterobacter is often readily consumed by hydrogenotrophic methanogens or homoacetogenic bacteria (Lovley and Klug, 1983), or is used as electron donor by sulfate- and nitrate-reducing bacteria. Therefore, activity of these different types of $\mathrm{H}_{2}$-utilizing microorganisms must be inhibited, while preserving activity of $\mathrm{H}_{2}$-producing bacteria. For this, seed sludge of $\mathrm{H}_{2}$ producing anaerobic reactors is often pre-treated with heat, electric current, air, or chemicals (e.g., bases, acids, or specific inhibitors). Heat treatment has been commonly used for inactivating methanogenic archaea; this method also allows a screening for $\mathrm{H}_{2}$-producing bacteria, as many of these mesophilic bacteria are spore-formers (Lay et al., 1999). However, it has been reported that, heat treatment was unable to completely inhibit $\mathrm{H}_{2}$-consuming microorganisms (Oh et al., 2003). Addition of chemicals, such as 2-bromoethanesulfonate (BES), an analogue of coenzyme M in methanogens and inhibitor of methane-producing archaea (Dimarco et al., 1990; Sparling et al., 1997), and chloroform, known to inhibit methanogenesis and possibly hydrogen-dependent homoacetogenesis (Chidthaisong and Conrad, 2000), may aid in the overall inhibition of $\mathrm{H}_{2}{ }^{-}$ utilizers. High rate anaerobic reactors, such as the expanded granular sludge bed (EGSB) reactor, can be applied for hydrogen production. However, microbial selection and development of $\mathrm{H}_{2}$-producing granules from suspended 
sludge requires a long start-up time $(\mathrm{Mu}$ and $\mathrm{Yu}, 2006 ; \mathrm{Yu}$ and $\mathrm{Mu}, 2006$; Zhang et al., 2007). Using environmental pressure for promoting the development of $\mathrm{H}_{2}$-producing microorganisms already present in matured anaerobic granules can be used as a strategy for decreasing start-up times of high rate $\mathrm{H}_{2}$-producing reactors as it eliminates the need for a granulation period ( $\mathrm{Hu}$ and Chen, 2008; Kotsopoulos et al., 2006). Nevertheless, methods to inhibit $\mathrm{H}_{2}$-consuming microorganisms may have an effect on the structural and morphological properties of granular sludge. Morphological parameters of $\mathrm{H}_{2}$-producing granules have been assessed only in few studies $(\mathrm{Mu}$ and $\mathrm{Yu}$, 2006; Zhang et al., 2008), and the effect of heat or chemical treatments on granules structure and integrity was never studied. Assessment of aggregates shape and size descriptors, such as free filaments length in the bulk, density of granules, and diameter of micro- or macro-aggregates, which have been suggested as suitable to quantify phenomena of granules erosion, fragmentation, and washout (Abreu et al., 2007; Amaral et al., 2004; Araya-Kroff et al., 2004; Costa et al., 2007), can give insights on the morphological changes deriving from heat or chemical treatment of matured anaerobic granules.

This work reports the first attempt to relate the macroand micro-scale morphology changes with microbial diversity shifts, in $\mathrm{H}_{2}$-producing granules.

\section{Materials and Methods}

\section{Sludge Source and Treatments}

Granular sludge was obtained from an industrial anaerobic reactor treating brewery wastewater. Volatile suspended solids (VSS) content of the sludge was $48 \mathrm{mg} \mathrm{VSS} \mathrm{g}^{-1}$. This sludge was submitted to different pretreatments in order to inhibit the activity of $\mathrm{H}_{2}$-consuming microorganisms, as shown in Table I.

\section{Experimental Setup}

The experiments were carried out in three EGSB reactors with an overall height of $1.95 \mathrm{~m}$ and an internal diameter of $21 \mathrm{~mm}$. Total volume was $1.30 \mathrm{~L}$ and working volume $0.7 \mathrm{~L}$. Reactors $R_{\text {Heat }}$, $R_{B E S}$, and $R_{B E S}+$ Chlo were inoculated with $400 \mathrm{~mL}$ of differently treated anaerobic granular sludge, $\mathrm{S}_{\text {Heat }}, \mathrm{S}_{\mathrm{BES}}$, and $\mathrm{S}_{\mathrm{BES}+\text { Chlo, respectively (treatments }}$ described above). Reactors were operated continuously and fed with a mixture of glucose $(13 \mathrm{mM})$ and L-arabinose $(16 \mathrm{mM})$ with a total chemical oxygen demand (COD) concentration of $5 \mathrm{~g} \mathrm{~L}^{-1}$. A mixture of a hexose and a pentose was used in this study as substrate model, since the efficient microbial fermentation of hexoses and pentoses is the key step for $\mathrm{H}_{2}$ production from cellulosic materials. Macronutrients, necessary for cell growth, were added to the feed $\left(0.6 \mathrm{~mL} \mathrm{~g}^{-1} \mathrm{COD}\right.$ of a stock solution containing $30 \mathrm{~g} \mathrm{~L}^{-1} \mathrm{MgSO}_{4} \cdot 7 \mathrm{H}_{2} \mathrm{O}, 28.3 \mathrm{~g} \mathrm{~L}^{-1} \mathrm{KH}_{2} \mathrm{PO}_{4}$, and $170 \mathrm{~g} \mathrm{~L}^{-1} \mathrm{NH}_{4} \mathrm{Cl}$ ). Sodium bicarbonate was added as alkalinity source $\left(1-2 \mathrm{~g} \mathrm{~L}^{-1}\right)$ and $\mathrm{pH}$ was kept at approximately 5.5. Reactors were heated at $37 \pm 1^{\circ} \mathrm{C}$ by means of an external jacket for water circulation. Hydraulic retention time (HRT) was of $20 \mathrm{~h}$ during the first 40 days; afterwards HRT was decreased to $12 \mathrm{~h}$. Superficial velocity was set at $8.0 \mathrm{~m} \mathrm{~h}^{-1}$ by using an internal liquid recirculation. A pulse of BES $(15 \mathrm{mM})$ was added to $\mathrm{R}_{\mathrm{BES}}$ on day 57 of

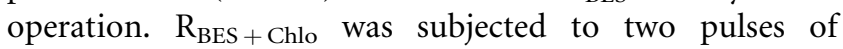
BES + chloroform (15 mM and $30 \mu \mathrm{M}$, respectively) on days 57 and 85 , and to a pulse of chloroform on day 73 of operation.

\section{Routine Analysis}

COD and VSS were determined according to standard methods (APHA, 1989). Biogas flow rate was measured by a Ritter Milligascounter (Dr. Ing. Ritter Apparatebau GmbH, Bochum, Germany). Hydrogen and methane content of gas was determined by gas chromatography. Hydrogen was measured using a Hayesep Q column (80/100 mesh) and a thermal conductivity detector (Varian 3300 Gas Chromoatograph), with nitrogen $\left(30 \mathrm{~mL} \mathrm{~min}^{-1}\right)$ as the carrier gas; injector, detector, and column temperatures were 120,170 , and $35^{\circ} \mathrm{C}$, respectively. Methane was measured using a Porapack Q column (100-180 mesh) and a thermal conductivity detector, with helium $\left(30 \mathrm{~mL} \mathrm{~min}^{-1}\right)$ as the carrier gas; temperatures of the detector, injector, and oven were 110,110 , and $35^{\circ} \mathrm{C}$, respectively. Volatile fatty acids (VFA), lactic acid, ethanol, L-arabinose, and glucose were determined by high performance liquid chromatography (Jasco, Japan) using a Chrompack column $\left(6.5 \times 30 \mathrm{~mm}^{2}\right)$. Sulphuric acid $(0.01 \mathrm{~N})$ at a flow rate of $0.7 \mathrm{~mL} \mathrm{~min}^{-1}$ was used as mobile phase; column temperature was set at $60^{\circ} \mathrm{C}$. After elution compounds were sequentially detected using two detectors: a UV detector at $210 \mathrm{~nm}$ for VFA and lactic acid, and a RI detector for measuring ethanol, L-arabinose, and glucose.

Table I. Thermal and chemical pre-treatments applied to anaerobic inocula.

\begin{tabular}{lll}
\hline Reactor & Inoculum & \multicolumn{1}{c}{ Treatment } \\
\hline $\mathrm{R}_{\text {Heat }}$ & $\mathrm{S}_{\mathrm{Heat}}$ & Heat treatment (granular sludge was boiled at $100^{\circ} \mathrm{C}$ for $\left.15 \mathrm{~min}\right)$ \\
$\mathrm{R}_{\mathrm{BES}}$ & $\mathrm{S}_{\mathrm{BES}}$ & BES treatment (granular sludge was incubated for $72 \mathrm{~h}$ at $37^{\circ} \mathrm{C}$ with $15 \mathrm{mM}$ 2-bromoethanesulfonate $(\mathrm{BES})$ ) \\
$\mathrm{R}_{\mathrm{BES}+\text { Chlo }}$ & $\mathrm{S}_{\mathrm{BES}+\text { Chlo }}$ & $\mathrm{BES}+$ Chloroform treatment (granular sludge was incubated for $72 \mathrm{~h}$ at $37^{\circ} \mathrm{C}$ with $15 \mathrm{mM} \mathrm{BES} \mathrm{plus} 30 \mu \mathrm{M}$ chloroform) \\
\hline
\end{tabular}


Table II. Samples collected for DGGE analysis from $\mathrm{R}_{\mathrm{Heat}}, \mathrm{R}_{\mathrm{BES}}$, and $\mathrm{R}_{\mathrm{BES}}+$ Chlo and correspondent operational conditions at time of sampling.

\begin{tabular}{lcccc}
\hline Treatments & Samples & Time (day) & HRT (h) & OLR $\left(\operatorname{kg~COD~m}^{-3} \mathrm{~d}^{-1}\right)$ \\
\hline Heat & $\mathrm{R}_{\text {Heat }} 1$ & 40 & 20 & 6.40 \\
& $\mathrm{R}_{\text {Heat }} 2$ & 57 & 12 & 10.66 \\
& $\mathrm{R}_{\text {Heat }} 3$ & 64 & 12 & 10.66 \\
BES & $\mathrm{R}_{\mathrm{BES}} 1$ & 40 & 20 & 6.40 \\
& $\mathrm{R}_{\mathrm{BES}} 2$ & 73 & 12 & 10.66 \\
\multirow{5}{*}{ BES + Chlor } & $\mathrm{R}_{\mathrm{BES}} 3$ & 97 & 12 & 10.66 \\
& $\mathrm{R}_{\mathrm{B}+\mathrm{C}} 1$ & 40 & 20 & 6.40 \\
& $\mathrm{R}_{\mathrm{B}+\mathrm{C}} 2$ & 73 & 12 & 10.66 \\
& $\mathrm{R}_{\mathrm{B}+\mathrm{C}^{3}}$ & 98 & 12 & 10.66 \\
\hline
\end{tabular}

OLR corresponds to organic loading rate and HRT to hydraulic retention time.

\section{Biomass Characterization}

The pre-treated granules, that is, $\mathrm{S}_{\mathrm{Heat}}, \mathrm{S}_{\mathrm{BES}}$, and $\mathrm{S}_{\mathrm{BES}+\text { Chlo, }}$ as well as samples withdrawn from the reactors according to Table II, were stored at $-18^{\circ} \mathrm{C}$ for further molecular analysis and at $4^{\circ} \mathrm{C}$ for image analysis. An additional sample collected at day 11 from $\mathrm{R}_{\mathrm{BES}}$ and $\mathrm{R}_{\mathrm{BES}}+$ Chlo was included for image analysis.

\section{Morphological properties}

\section{Sludge Sampling and Processing for Image Analysis}

Sludge sampling and processing were performed according to Araya-Kroff et al. (2004). Details provided in Supplementary Material.

\section{Image Acquisition and Analysis}

Three sets of about 100 images were acquired for each sample in order to optimize image quality for detection and quantification. Images used to quantify macro-aggregates (equivalent diameter $\left(D_{\text {eq }}\right) \quad \geq 0.2 \mathrm{~mm}$ ) were acquired through visualization on a SZ 40 stereo microscope (Olympus, Tokyo, Japan) with $15 \times$ magnification. Images used to quantify filaments and micro-aggregates $\left(D_{\text {eq }}\right)<0.2 \mathrm{~mm}$ ) were acquired through phase contrast and bright field, respectively, on a Diaphot 300 microscope (Nikon Corporation, Tokyo, Japan) with $100 \times$ magnification. All the images were digitized with a CCD AVC D5CE gray scale video camera (Sony, Tokyo, Japan) and a DT 3155 frame grabber (Data Translation, Marlboro, MA) with $768 \times 576$ pixel size with 8 bits (256 gray levels) by Image Pro Plus (Media Cybernetics, Silver Spring, MD). Image processing and analysis was done by means of Matlab (The Mathworks, Inc., Natick, MA) constructed applications (Walsby and Avery, 1996). More details are provided in Supplementary Material.

Morphological parameters (i) free filaments length (TL) and (ii) percentage of total projected area of aggregates (TA) for different equivalent diameter ranges were calculated (details are provided as Supplementary Material). Relative values were obtained by dividing TL by the VSS content. Apparent granule density was calculated by the ratio VSS/TA (Araya-Kroff et al., 2004). This set of parameters provides quantitative information about the aggregation state of the biomass.

\section{Microbial Community}

\section{DNA Extraction, PCR, and DGGE}

Total genomic DNA was extracted using a FastDNA SPIN kit for soil (Qbiogene, Carlsbad, CA). Bacterial 16S rRNA genes were selectively amplified for cloning using primers Bact27-f and Uni1492-r (Yu and Morrison, 2004). For DGGE analysis, DNA fragments of 456 base pairs were amplified by PCR using the primer set 954GC-f and 1369-r (Sanguinetti et al., 1994). DGGE analysis of the amplicons was done by using the DCode system (Bio-Rad, Hercules, CA) as described in detail by Abreu et al. (2010). DGGE profiles were compared using the Bionumerics 5.0 software package (Applied Maths, Sint-Martens-Latem, Belgium). Similarity indices (SI) of the compared profiles were calculated from the densitometric curves of the scanned DGGE profiles by using the Pearson product-moment correlation (Cole et al., 2003). Community shifts were described as changes in the DGGE profiles of the partial $16 \mathrm{~S}$ rDNA amplicons.

Shannon Wiener diversity indices $(H)$ were calculated on the basis of the intensities of the bands on the gel tracks, as judged by peak height in the densitometric curves, according to the equation: $H=-\Sigma\left(P_{\mathrm{i}} \ln \left(P_{\mathrm{i}}\right)\right)$ where, $H$ is the diversity index and $P_{\mathrm{i}}$ is the importance probability of the bands in a lane $\left(P_{\mathrm{i}}=n_{\mathrm{i}} / N\right.$, where $n_{\mathrm{i}}$ is the height of an individual peak and $N$ is the sum of all peak heights in the densitometric curves).

\section{Cloning and Sequencing}

Cloning of PCR products, transformation, and selection of transformants to be subjected to DNA sequence analysis, through amplified ribosomal DNA analyzes (ARDRA) and DGGE mobility were performed as previously described in detail by Abreu et al. (2010). Sequencing reactions were performed at BIOPREMIER (Lisbon, Portugal) using pGEM-T vector-targeted sequencing primers SP6, T7, and internal specifically tailored primers, when needed.

\section{Phylogenetic Analysis}

$16 \mathrm{~S}$ rRNA gene partial sequences were assembled using the CAP application included in the BioEdit v7.0.9 software package (Hall, 1999). Consensus sequences were checked for potential chimera artifacts by the CHECK_CHIMERA program of the Ribosomal Database Project II (Cole 
et al., 2003). Similarity searches for the assembled $16 \mathrm{~S}$ rRNA gene sequences were performed using the NCBI BLAST search program within the GenBank database (Thompson et al., 1994). Phylogenic assignment of the sequences to higher-order taxa was performed using the RDP Naive Bayesian Classifier. 16S rRNA sequences were further aligned by using the FastAligner v1.03 tool of the ARB program package (Olsen et al., 1994). The resulting alignments were manually checked and corrected when necessary, and unambiguously aligned nucleotide positions were used for the construction of a 16S rRNA gene-based phylogenetic tree by using the FastDNAMI method (Hu and Chen, 2007). Phylogenetic placement was performed in comparison with reference sequences, with Felsenstein correction and application of appropriated filters at the respective phylum level. Nearly, complete 16S rRNA sequences of the 16S rRNA gene clones were deposited in the GenBank database under accession numbers GU907811-GU907825.

\section{Results}

\section{Hydrogen Production in Continuous EGSB Reactors}

Hydrogen recovery in $\mathrm{R}_{\text {Heat }}$, inoculated with heat-treated granular sludge, was minor during the first operation period (HRT $20 \mathrm{~h}$ ) (Fig. 1a). Acetate and butyrate were the main VFA measured in the bulk and methane was not detected, which indicates that produced hydrogen was most likely being channeled to homoacetogenesis. Homoacetogenic activity on $\mathrm{H}_{2} / \mathrm{CO}_{2}$ was further confirmed in batch experiments (data not shown). A peak of lactic acid $(23 \mathrm{mM})$ was observed at the end of the first operation
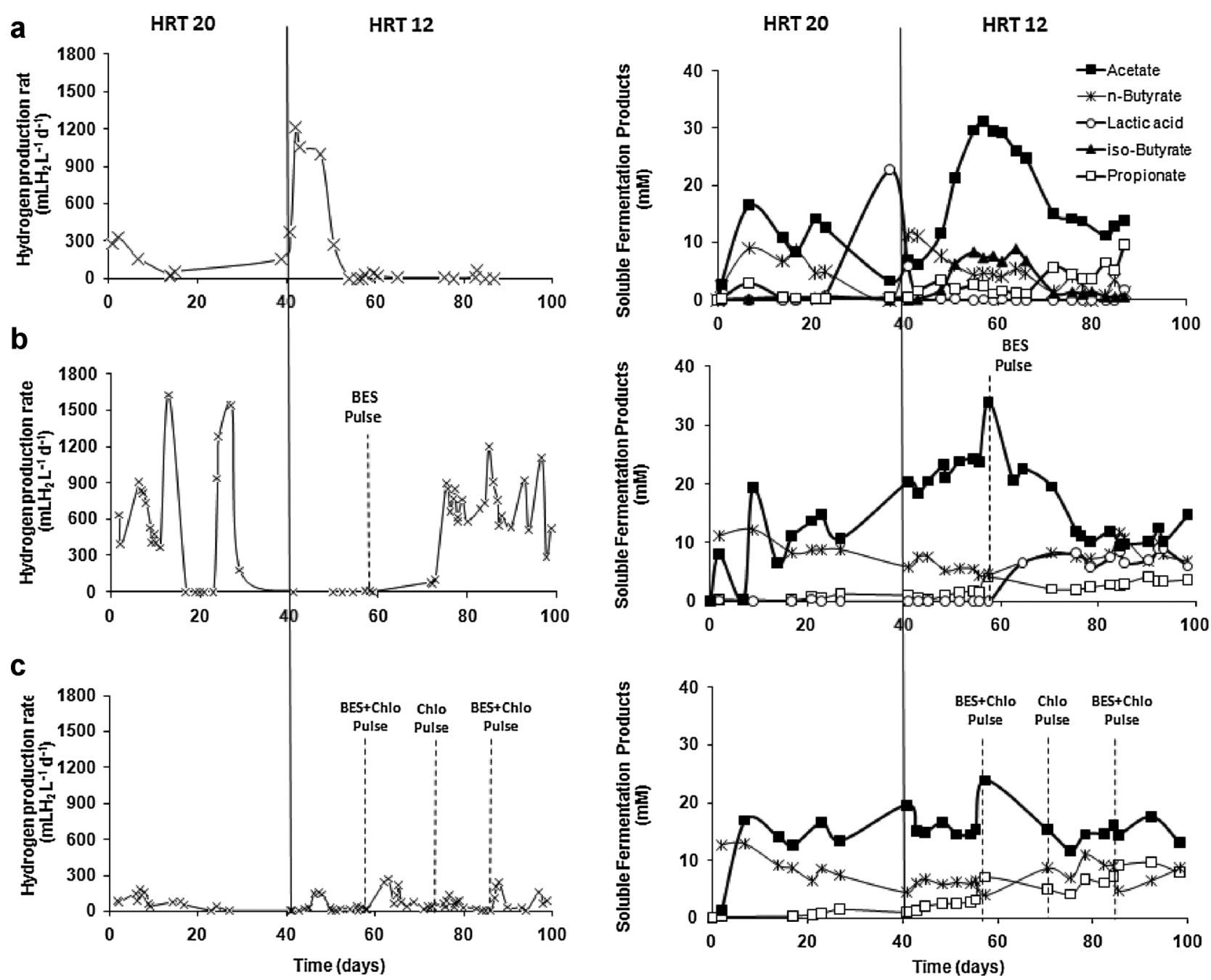

Figure 1. Time course of hydrogen production rate and soluble microbial products profile in $R_{H e a t}(a), R_{B E S}(\mathbf{b})$, and $R_{B E S}+$ Chlo $(\mathbf{c})$. Pulses of $B E S$ and chloroform applied, as well as the hydraulic retention time (HRT) set at each operation period are signaled in the figure. 
period, coincident with a severe decrease in $n$-butyrate and acetate concentration. After setting the HRT at $12 \mathrm{~h}$, lactic acid concentration decreased and, simultaneously, $n$-butyrate concentration and hydrogen production rate increased to values of up to $11 \mathrm{mM}$ and $1,100 \mathrm{~mL} \mathrm{H}_{2} \mathrm{~L}^{-1}$ day ${ }^{-1}$, respectively. This high hydrogen production rate was transient and, after 10 days, decreased to negligible values. Coincidently, acetate concentration rose up to a maximum of $31 \mathrm{mM}$. Propionate concentration during the second operation period of $\mathrm{R}_{\text {Heat }}$ increased to up to $10 \mathrm{mM}$. Higher propionate formation, coupled with homoacetogenesis, might justify the absence of hydrogen production after day 50 of operation.

$\mathrm{R}_{\mathrm{BES}}$ and $\mathrm{R}_{\mathrm{BES}}+$ Chlo showed unstable hydrogen production and apparent homoacetogenesis during the first period of operation (HRT 20 h) (Fig. 1a and b). During this first period, ethanol concentration increased up to $8 \mathrm{mM}$, in both reactors (data not shown), and butyrate concentration decreased from approximately $12 \mathrm{mM}$ to nearly $5 \mathrm{mM}$ on average. After decreasing HRT to $12 \mathrm{~h}$, an increase on propionate concentration was observed in both reactors, up to values of 4 and $8 \mathrm{mM}$ in $\mathrm{R}_{\mathrm{BES}}$ and $\mathrm{R}_{\mathrm{BES}}+$ Chlo, respectively. Homoacetogenesis was apparently taking place in the two reactors, although more strongly in $\mathrm{R}_{\mathrm{BES}}$ where acetate peaked at a value as high as $34 \mathrm{mM}$ (Fig. 1b). Addition of a BES pulse to $R_{B E S}$ caused a decrease on acetate concentration to about $10 \mathrm{mM}$, but lactic acid concentration increased to $7 \mathrm{mM}$. Hydrogen production in $\mathrm{R}_{\mathrm{BES}}$ restarted at day 72 , when lactic acid and acetate concentrations were nearly at the same concentration (i.e., $7-10 \mathrm{mM}$ ) (Fig. 1b). From day 72 onwards, hydrogen production was observed in $\mathrm{R}_{\mathrm{BES}}$ with an average hydrogen production rate of $700 \pm 200 \mathrm{~mL} \mathrm{H}_{2} \mathrm{~L}^{-1}$ day $^{-1}$. Hydrogen production in $\mathrm{R}_{\mathrm{BES}}+$ Chlo was very low throughout all the operation time (Fig. 1c). Additional pulses of BES and chloroform did not prompt hydrogen production (Fig. 1c).

\section{Morphological Properties of Granular Sludge}

Image analysis was used to quantify changes in morphological properties of the granular sludge subjected to the different pretreatments.

Total free filaments length per VSS (TL/VSS) in the three reactors increased during the first operational period (TRH $20 \mathrm{~h}$ ) (Fig. 2a). This structural change was accompanied by a decrease in the amount of VSS per total projected area (VSS/ TA) (Fig. 2a), indicating the release of filaments from the granules. Granules did not fragment in $\mathrm{R}_{\mathrm{Heat}}$ during the first period of operation, as shown by the maintenance of the percentage of projected area of aggregates with $D_{\text {eq }}>1 \mathrm{~mm}$ (Fig. 2b). This was not the case for sludges in $\mathrm{R}_{\mathrm{BES}}$

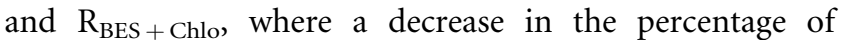
projected area of aggregates with $D_{\text {eq }}>1 \mathrm{~mm}$ was observed (Fig. 2b).

After changing the HRT to $12 \mathrm{~h}$, TL/VSS decreased and VSS/TA of aggregates increased, in all the reactors (Fig. 2a). $R_{\text {Heat }}$ showed the highest increase in VSS/TA,
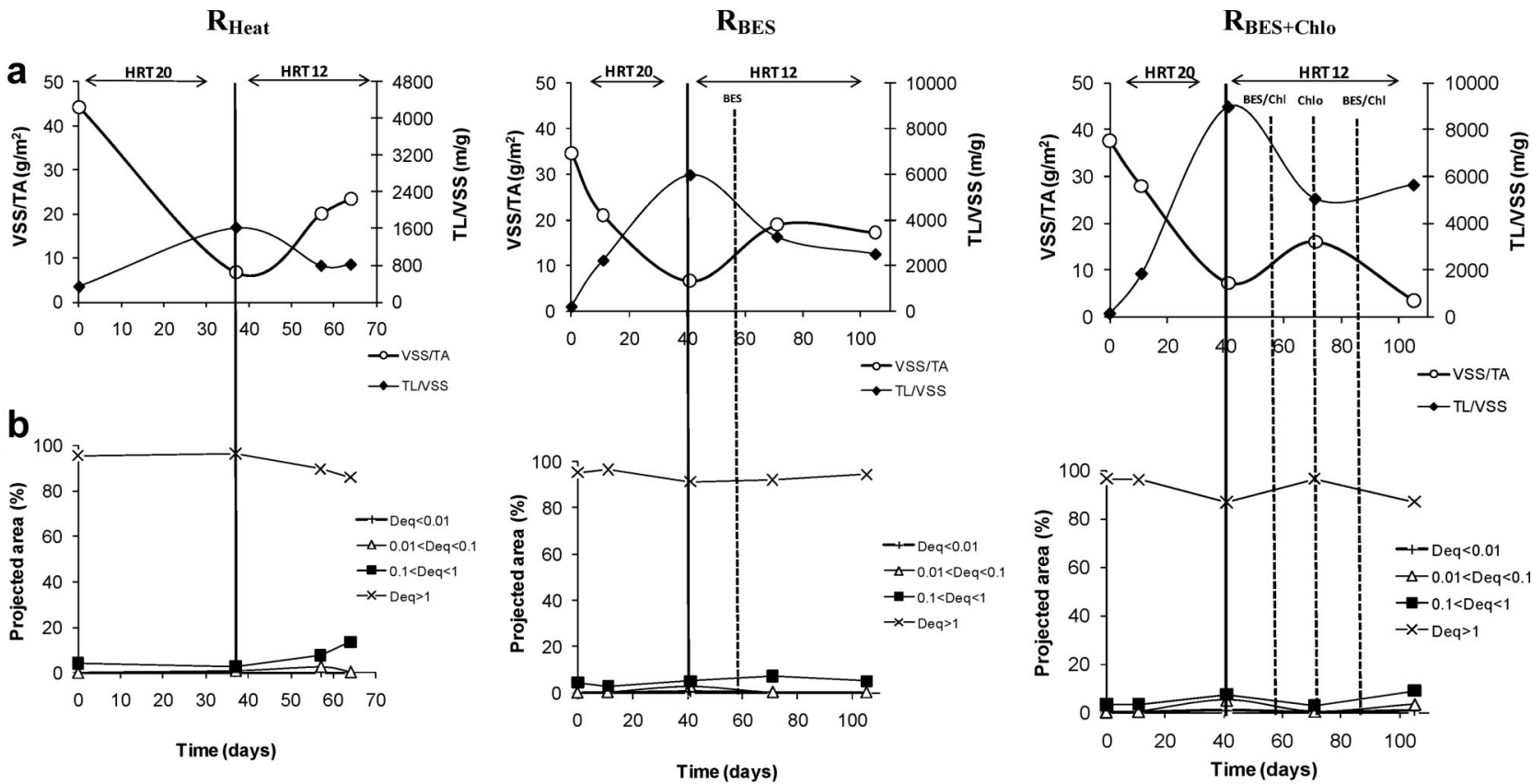

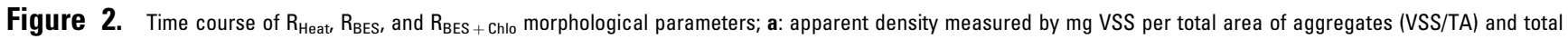
filaments length per VSS (TL/VSS); $\mathbf{b}$ : percentage of total projected area of aggregates within different equivalent diameters $\left(D_{\text {eq }}\right)$ ranges. 
achieving $24 \mathrm{~g} / \mathrm{m}^{2}$ at the end of operation. In this reactor, percentage of projected area of aggregates with $D_{\text {eq }}>1 \mathrm{~mm}$ decreased from $96 \%$ to $88 \%$, with consequent increase of the fraction of aggregates with $D_{\text {eq }}$ from 0.1 to $1 \mathrm{~mm}$. In $\mathrm{R}_{\mathrm{BES}}$, TL/VSS decreased (to approximately $2,700 \mathrm{~m} \mathrm{~g}^{-1}$ ) and VSS/ TA increased (up to $18 \mathrm{~g} \mathrm{~m}^{-2}$ ). Addition of a BES pulse did not affect the integrity of granules and the percentage of projected area of aggregates with $D_{\text {eq }}>1 \mathrm{~mm}$ kept a slightly increasing trend (Fig. 2b). In $\mathrm{R}_{\mathrm{BES}}+$ Chlo TL/VSS increased (to approximately $5,900 \mathrm{mg}^{-1}$ ) and a highly decrease in VSS/TA (to approximately $2 \mathrm{~g} \mathrm{~m}^{-2}$ ) was observed after the second pulse of BES + Chloroform. These changes were concurrent with granules fragmentation. Original images of filaments and macro-agregates, and correspondent binary images, obtained at the end of the operation of each reactor are shown in Figure 3 as an example.

\section{Bacterial Diversity}

Pre-treated sludges ( $\mathrm{S}_{\mathrm{Heat}}, \mathrm{S}_{\mathrm{BES}}$, and $\mathrm{S}_{\mathrm{BES}}+$ Chlo $)$, and samples withdrawn from the reactors along time, were analyzed regarding their bacterial diversity and composition (Table II, Fig. 4). DGGE profiles generated for each sludge sample were compared in terms of diversity index $(H)$ and similarity index $(\mathrm{SI})$. $\mathrm{S}_{\text {Heat }}$ presented a lower diversity $(H=0.31)$ than the chemically treated granules $(H=1.43$ and $H=1.20$ for $\mathrm{S}_{\mathrm{BES}}$ and $\mathrm{S}_{\mathrm{BES}}+$ Chlo, respectively) (Fig. 4). Shifts in the bacterial composition of reactor sludge samples during the first operation period were pronounced, with SI between the inoculum sludges and samples collected on day 40 (end of the first operational period, samples $\mathrm{R}_{\text {Heat }} 1, \mathrm{R}_{\mathrm{BES}} 1$, and $\mathrm{R}_{\mathrm{B}+\mathrm{C}} 1$ ) lower than $1 \%$ (Fig. 4). Bacterial diversity in $S_{\text {Heat }}$ was very low $(H=0.31)$, but increased with time; at end of operation, the diversity index in $\mathrm{R}_{\text {Heat }}$ was five-fold higher than initially (Fig. 4). Bacterial diversity in $\mathrm{R}_{\mathrm{BES}}+$ Chlo was not significantly affected $\left(H=1.26\right.$ and $H=1.28$ for $\mathrm{R}_{\mathrm{B}+\mathrm{C}} 1$ and $\mathrm{R}_{\mathrm{B}+\mathrm{C}^{2}}$, respectively), until the addition of a second pulse of chloroform that caused a drop in the bacterial diversity with a $H$ value of 0.72 for $\mathrm{R}_{\mathrm{B}+\mathrm{C}} 3$. The most stable bacterial diversity was observed in $\mathrm{R}_{\mathrm{BES}}$, with an average overall diversity index of $1.34 \pm 0.10$ (Fig. 4). Further characterization of the bacterial
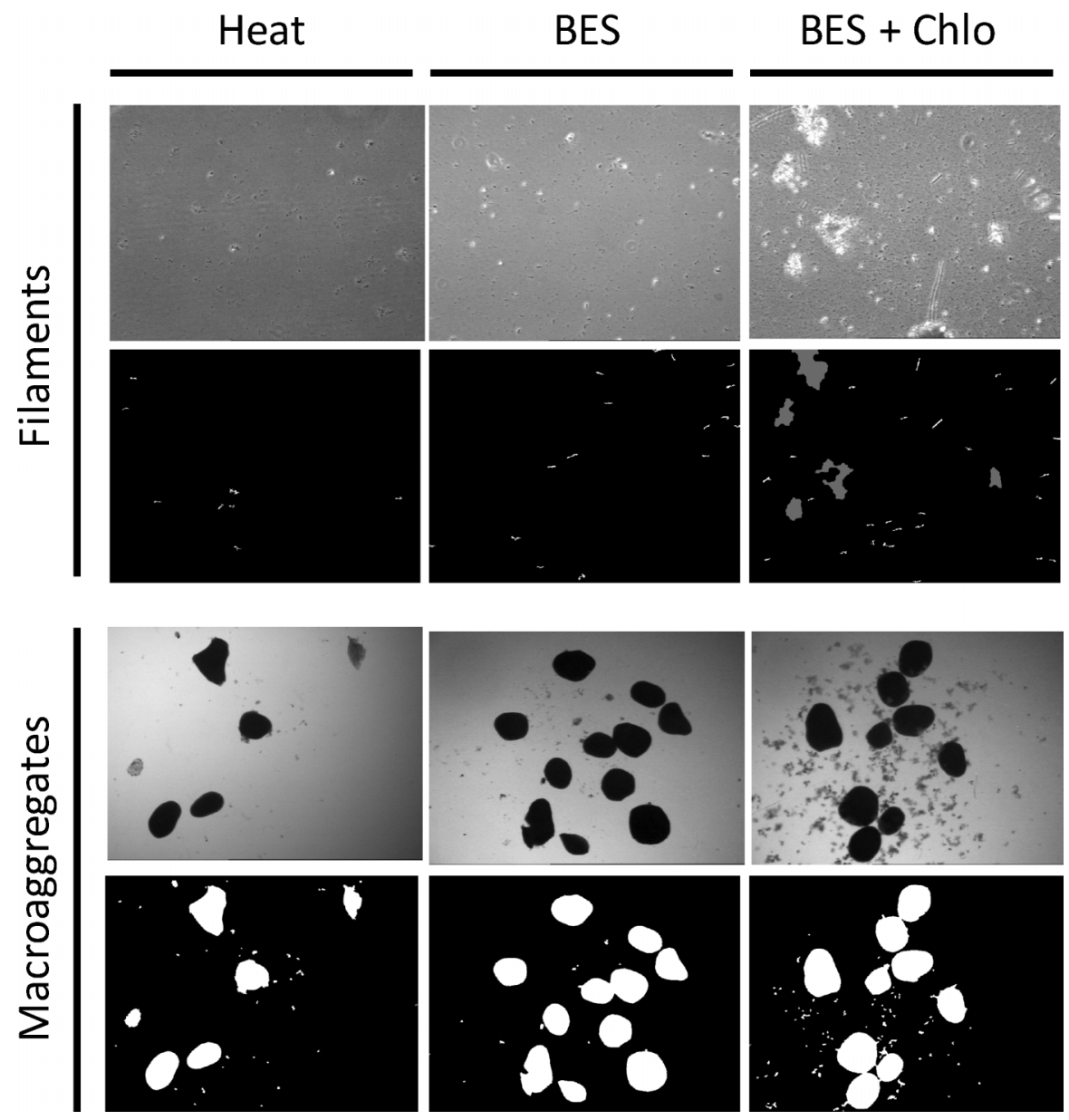

Figure 3. Example of original images of filaments (acquired using phase contrast with a magnification of $100 \times$ ) and macro-aggregates (acquired using a stereoscope with a magnification of $15 \times$ ), and respective binary images. 


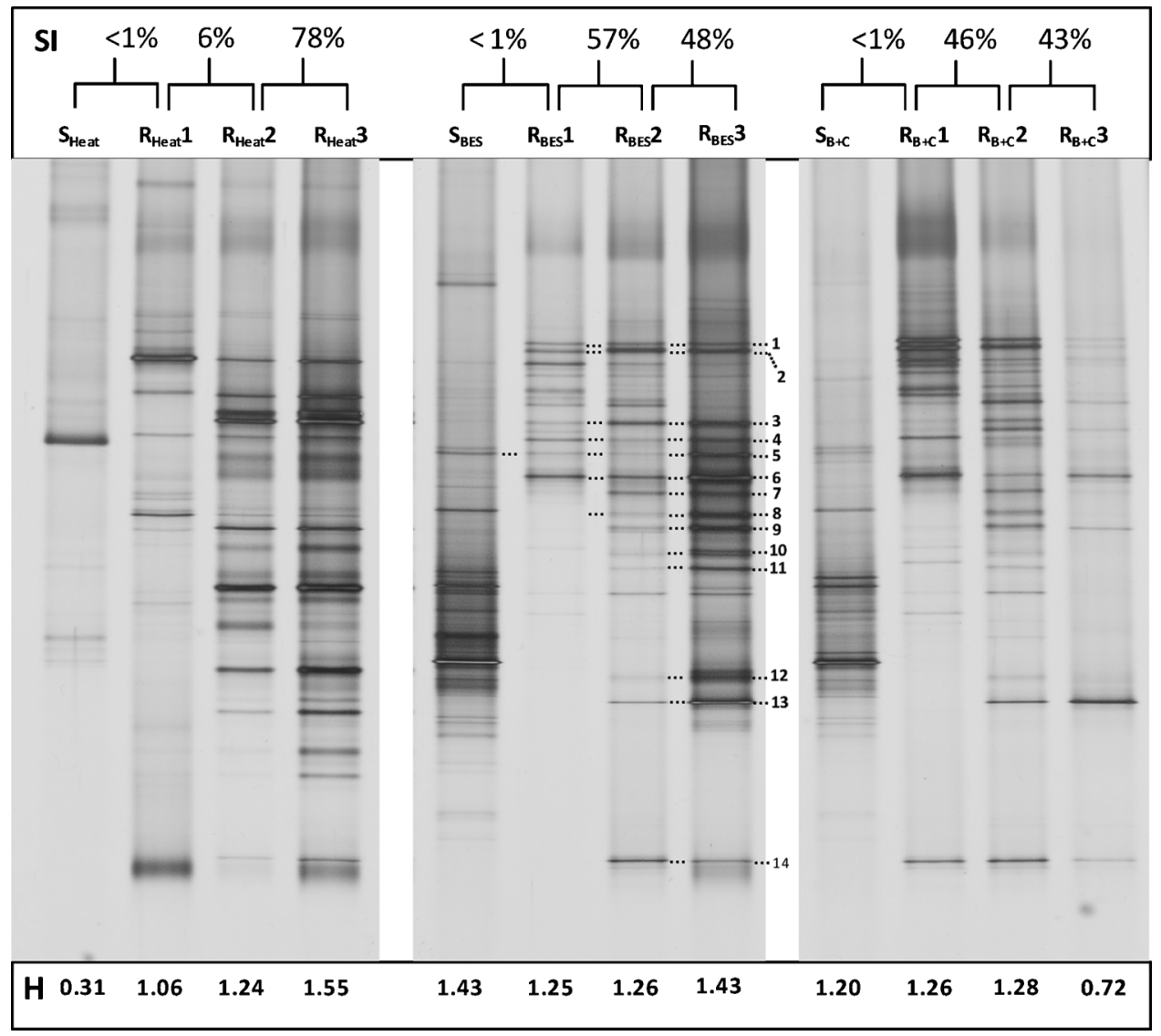

Figure 4. DGGE profiles of granules after heat treatment $\left(\mathrm{S}_{\mathrm{Heat}}\right)$; granules after the contact with $\mathrm{BES}\left(\mathrm{S}_{\mathrm{BES}}\right)$; granules after the contact with $\mathrm{BES}+\mathrm{Chloroform}\left(\mathrm{S}_{\mathrm{BES}}+\mathrm{Chlo}\right)$ and samples withdrawn from $R_{H e a t} R_{B E S}$, and $R_{B E S}+$ chlo along the operation according to Table II. Similarity (SI) and diversity $(H)$ indices.

community present in $\mathrm{R}_{\mathrm{BES}}$ was performed (Figs. 4 and 5). The dominant bacterial ribotypes displayed in the DGGE profiles along the $\mathrm{R}_{\mathrm{BES}}$ operation were found to be closely related to Clostridium species (Clostridium sp. (99\% identity), Clostridium ljungdahlii (99\%), Clostridium drakei (94\%), Clostridium ragsdalei (100\%)), and uncultured bacterium sequences belonging to Clostridiaceae and Ruminococcaceae families. $16 \mathrm{~S}$ rDNA clone sequences were used to construct the phylogenetic tree as given in Figure 5.

\section{Discussion}

In the last years, different methods have been studied for the effective development of anaerobic granular sludge for hydrogen production. All these methods have been studied in terms of hydrogen production and yields (Oh et al., 2003). In the present study, we evaluate the effect of heat treatment and two chemical treatments (contact with BES and with BES + Chloroform) on the macro- and micro-scale morphology and microbial community structure in the operation of high rate anaerobic reactors.
Heat treatment was inefficient for inhibiting propionate formers and homoacetogenic microorganisms, as previously reported by other authors (Tanner et al., 1993). Heat caused immediate and strong decrease in bacterial diversity of the granular sludge (Fig. 4), likely due to the elimination of $\mathrm{H}_{2}-$ consumers but also due to suppression of other bacteria. In fact, heat acts as a non-selective pressure enriching microbial sludges on spore-forming bacteria and not on specific physiological groups. Methanogens are normally eradicated, but homoacetogens can resist because some can form spores (Matsumoto and Nishimura, 2007). Chloroform is thought to be an inhibitor for homoacetogens, and it could actually inhibit some homoacetogenic activity; acetate concentration in $\mathrm{R}_{\mathrm{BES}}+$ Chlo was lower than in $\mathrm{R}_{\text {Heat }}$ and $\mathrm{R}_{\mathrm{BES}}$, especially after decreasing the HRT to $12 \mathrm{~h}$. Nevertheless, an increase on propionate formation in the presence of chloroform impaired a good overall hydrogen yield. After day 72, hydrogen production was observed in $\mathrm{R}_{\mathrm{BES}}$ (average hydrogen production rate of $700 \pm 200 \mathrm{~mL} \mathrm{H}_{2} \mathrm{~L}^{-1}$ day $^{-1}$ ). Hydrogen production in this reactor was linked to the consumption of acetate and lactate. Production of hydrogen, carbon dioxide, and butyrate from acetate and lactic 


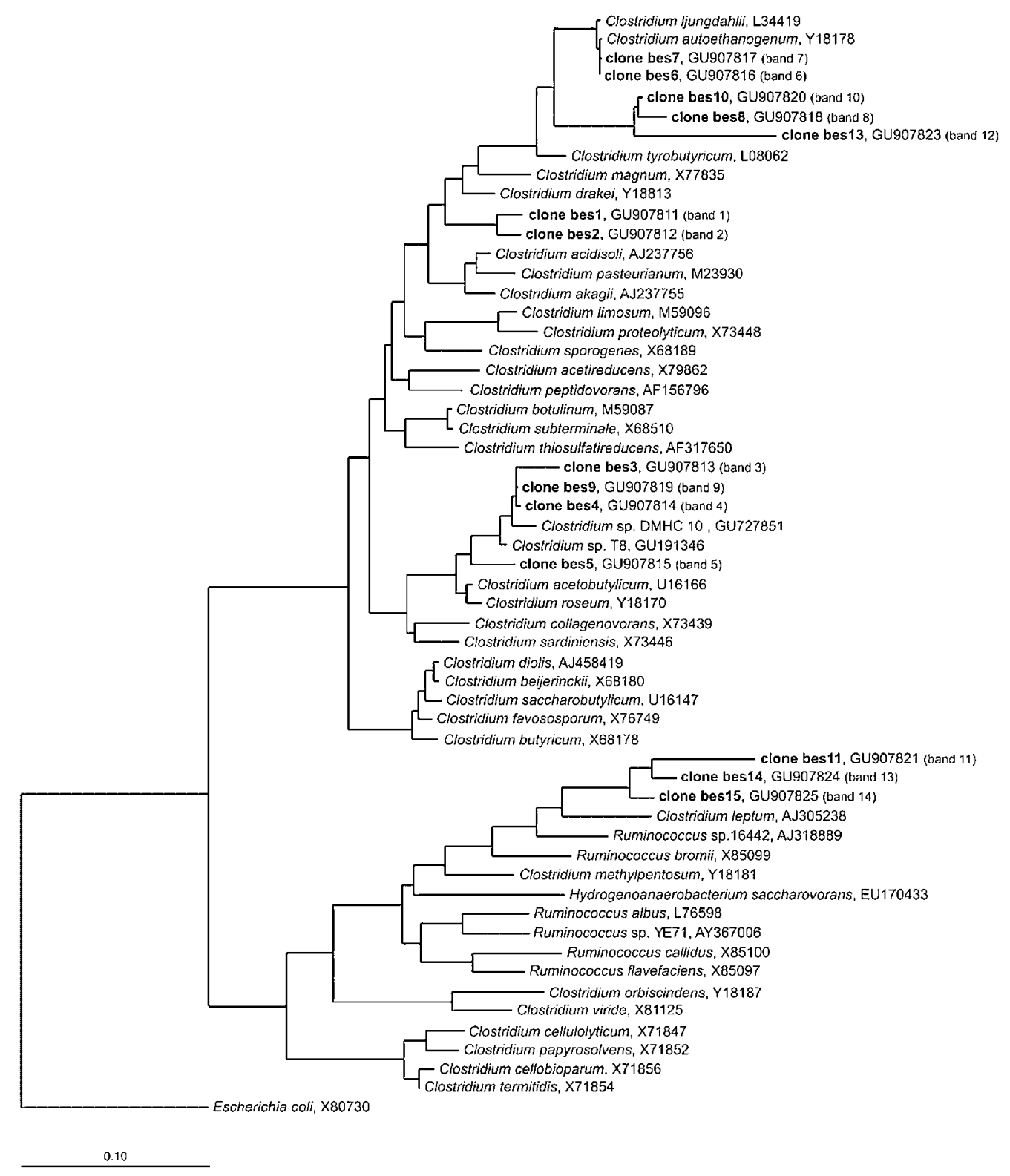

Figure 5. FastDNAMI tree of partial $16 \mathrm{~S}$ rRNA gene sequences from $\mathrm{R}_{\mathrm{BES}}$ clones and closest relatives imported from NCBI database. GenBank accession numbers of $16 \mathrm{~S}$ rRNA gene sequences used to construct the tree are shown; DGGE bands corresponding to each of the sequenced clones is given in parentheses. Bar corresponds to $1 \%$ sequence divergence.

acid has been reported for Clostridium diollis (Lay et al., 1999). These results demonstrate that, some routes for hydrogen production are not only dependent on the presence of hydrogen producers but also on the cometabolism of the whole microbial community.

Besides the microbial and metabolic aspects, granular sludge should maintain the morphological properties and integrity essential for high rate reactors operation. When granular sludge deteriorates, a release of filaments and/or fragments can occur, simultaneously with the decrease in density and/or size of the aggregates. Sludge washout is usually an immediate consequence, due to the low hydraulic retention times usually applied in high rate reactors, leading ultimately to process failure.

In this work, during the first period of operation (TRH $20 \mathrm{~h}$ ), an increase of filaments release and a decrease of granules density were observed in all the reactors. The effluent VSS increased and a considerable shift on the microbial population was observed (SI $<1 \%$, Fig. 4$)$. This initial washout enabled the microbial selection process imposed by the different treatment strategies. Chemically treated sludges showed higher filaments release than heat- 
treated sludge (VSS in the effluent increased approximately and $2.4 \times$ for $\mathrm{R}_{\mathrm{BES}}+$ Chlo, $2 \times$ for $\mathrm{R}_{\mathrm{BES}}$, and $1.3 \times$ for $\mathrm{R}_{\text {Heat }}$ ).

During the second period of operation, bacterial community in $\mathrm{R}_{\text {Heat }}$ showed lower fluctuations and seemed to stabilize. Simultaneously, considerable changes occurred in terms of morphological properties resulting in a significant increase on the apparent granules density (Fig. 2a and b). Contrarily, considerable modifications were observed along $\mathrm{R}_{\mathrm{BES}}$ operation in the microbial community even though granules apparent density has been maintained roughly at $20 \mathrm{~g} \mathrm{~m}^{-2}$ and significant filaments release was not observed. This means that some organisms were being released from the aggregated structure of granular sludge and replaced by others, but this dynamic did not affect the granules morphology and density. Bacterial diversity in $\mathrm{R}_{\mathrm{BES}}+$ Chlo decreased notably after the addition of a second chloroform pulse (Fig. 4). This fact was coincident with a considerable decrease of granules density (VSS/TA of $2 \mathrm{~g} \mathrm{~m}^{-2}$ ) and increase of filaments release (TL/VSS of 5,900 $\mathrm{m} \mathrm{g}^{-1}$ ) (Fig. 2a), concurrent with the fragmentation of granules. Granule fragmentation was also observed in $\mathrm{R}_{\text {Heat }}$ during the second period of operation. Opposite behavior was observed in $\mathrm{R}_{\mathrm{BES}}$; this system maintained along the operation time, the percentage of projected area of aggregates with an equivalent diameter larger than $1 \mathrm{~mm}$.

The chemical pre-treatment strategy using BES + Chloroform lead to granules deterioration, but the application of BES only, showed higher hydrogen production potential and did not affect significantly the granules integrity. This strategy revealed higher potential for high rate systems, since it was more capable of maintaining higher biomass concentration under high dilution rates without biomass washout.

Results obtained for the bacterial composition in $\mathrm{R}_{\mathrm{BES}}$ are in agreement with several studies that have suggested that Clostridium-like bacteria are the dominant microorganisms present in $\mathrm{H}_{2}$-producing systems (Song and Dong, 2009). Interestingly, 16S rDNA sequences phylogeneticaly positioned within the Ruminococcaceae family were also found in $\mathrm{R}_{\mathrm{BES}}$. Recently a novel bacterium from the Ruminococcacea family, Hydrogenoanaerobacterium saccharovans, was isolated from a $\mathrm{H}_{2}$-producing UASB reactor. This non-spore former organism can use different mono-, di-, and oligosaccharides to produce acetate, ethanol, hydrogen, and carbon dioxide. The fact that some hydrogen producers are non-spore formers highlights the importance of using different methods, for directing granular sludge for optimal hydrogen production, as an alternative to the methods based on the stimulation of spore formation. The presence of organisms closely related to Clostridium ljungdahlii and Clostridium autoethanogenum might possibly explain the high acetate concentration and low hydrogen production observed in $\mathrm{R}_{\mathrm{BES}}$ before day 72 . These acetogenic organisms can use several substrates to produce acetate including hydrogen and carbon dioxide, decreasing the overall hydrogen production rate.

\section{Conclusions}

Chemical and heat treatment strategies applied to suppress $\mathrm{H}_{2}$-consuming microorganisms were shown to affect macro- and micro-scale structure and microbiology of granular sludge. Among the three strategies applied, pretreatment and subsequent pulses with BES revealed to be the one with higher potential for high-rate reactors start-up and operation, at mesophilic conditions. This procedure was effective in extinguishing the methanogenic hydrogenotrophic activity and did not extensively affect macro- and microstructure of the granules. However, homoacetogenic activity could not be completely inhibited, lowering the hydrogen production yields. Further studies are needed to get more insights in the role of homoacetogens in the dark fermentation processes. This is important to define effective strategies for complete suppression of these microorganisms.

The financial support from Fundação para a Ciência e Tecnologia (FCT) and European Community fund FEDER, trough Program COMPETE, in the ambit of the Project FCOMP-01-0124-FEDER007087 (PTDC/BIO/69745/2006), and trough the FCT PhD grants SFRH/BD/29823/2006 given to A.A Abreu and SFRH/BD/48965/2008 given to J I Alves is gratefully acknowledged.

\section{References}

Abreu AA, Costa JC, Araya-Kroff P, Ferreira EC, Alves MM. 2007. Quantitative image analysis as a diagnostic tool for identifying structural changes during a revival process of anaerobic granular sludge. Water Res 41:1473-1480.

Abreu AA, Alves JI, Pereira MA, Karakashev D, Alves MM, Angelidaki I. 2010. Engineered heat treated methanogenic granules: A promising biotechnological approach for extreme thermophilic biohydrogen production. Bioresour Technol 101:9577-9586.

Amaral AL, Pereira MA, da Motta M, Pons MN, Mota M, Ferreira EC, Alves MM. 2004. Development of image analysis techniques as a tool to detect and quantify morphological changes in anaerobic sludge: II. Application to a granule deterioration process triggered by contact with oleic acid. Biotechnol Bioeng 87:194-199.

APHA AW. Standard methods for the examination of water and wastewater, 17th edn. Washington: American Public Health Association. 1989. Ref Type: Generic.

Araya-Kroff P, Amaral AL, Neves L, Ferreira EC, Pons MN, Mota M, Alves MM. 2004. Development of image analysis techniques as a tool to detect and quantify morphological changes in anaerobic sludge: I. Application to a granulation process. Biotechnol Bioeng 87:184-193.

Chidthaisong A, Conrad R. 2000. Specificity of chloroform, 2-bromoethanesulfonate and fluoroacetate to inhibit methanogenesis and other anaerobic processes in anoxic rice field soil. Soil Biol Biochem 32:977988.

Cole JR, Chai B, Marsh TL, Farris RJ, Wang Q, et al. 2003. The ribosomal database project (RDP-II): Previewing a new autoaligner that allows regular updates and the new prokaryotic taxonomy. Nucleic Acids Res 31:442-443.

Costa JC, Abreu AA, Ferreira EC, Alves MM. 2007. Quantitative image analysis as a diagnostic tool for monitoring structural changes of anaerobic granular sludge during detergent shock loads. Biotechnol Bioeng 98:60-68.

Dimarco AA, Bobik TA, Wolfe RS. 1990. Unusual coenzymes of methanogenesis. Annu Rev Biochem 59:355-394. 
Hall TA. 1999. BioEdit: A user-friendly biological sequence alignment editor and analysis program for Windows 95/98/NT. Nucl Acids Symp Ser 41:95-98.

Hu B, Chen SL. 2007. Pretreatment of methanogenic granules for immobilized hydrogen fermentation. Int J Hydrogen Energy 32:32663273.

Hu B, Chen SL. 2008. Biological hydrogen production using chloroformtreated methanogenic granules. Appl Biochem Biotechnol 148: 83-95.

Kleerebezem R, van Loosdrecht MCM. 2007. Mixed culture biotechnology for bioenergy production. Curr Opin Biotechnol 18:207-212.

Kotsopoulos TA, Zeng RJ, Angelidaki I. 2006. Biohydrogen production in granular up-flow anaerobic sludge blanket (UASB) reactors with mixed cultures under hyper-thermophilic temperature (70 degrees C). Biotechnol Bioeng 94:296-302.

Lay JJ, Lee YJ, Noike T. 1999. Feasibility of biological hydrogen production from organic fraction of municipal solid waste. Water Res 33:25792586.

Lovley DR, Klug MJ. 1983. Methanogenesis from methanol and methylamines and acetogenesis from hydrogen and carbon-dioxide in the sediments of a eutrophic lake. Appl Environ Microbiol 45:1310 1315.

Matsumoto M, Nishimura Y. 2007. Hydrogen production by fermentation using acetic acid and lactic acid. J Biosci Bioeng 103:236241.

Mu Y, Yu HQ. 2006. Biological hydrogen production in a UASB reactor with granules. I: Physicochemical characteristics of hydrogen-producing granules. Biotechnol Bioeng 94:980-987.

Oh SE, Van Ginkel S, Logan BE. 2003. The relative effectiveness of $\mathrm{pH}$ control and heat treatment for enhancing biohydrogen gas production. Environ Sci Technol 37:5186-5190.

Olsen GJ, Matsuda H, Hagstrom R, Overbeek R. 1994. Fastdnaml-A tool for construction of phylogenetic trees of DNA-sequences using maximum-likelihood. Comput Appl Biosci 10:41-48.
Sanguinetti CJ, Neto ED, Simpson AJG. 1994. Rapid silver staining and recovery of PCR products separated on polyacrylamide gels. Biotechniques 17:914-921.

Song L, Dong XZ. 2009. Hydrogenoanaerobacterium saccharovorans gen. nov., sp nov., isolated from $\mathrm{H}$-2-producing UASB granules. Int J Syst Evol Microbiol 59:295-299.

Sparling R, Risbey D, PoggiVaraldo HM. 1997. Hydrogen production from inhibited anaerobic composters. Int J Hydrogen Energy 22:563-566.

Tanner RS, Miller LM, Yang D. 1993. Clostridium-ljungdahlii sp-nov, an acetogenic species in clostridial ribosomal-RNA homology group-I. Int J Syst Bacteriol 43:232-236.

Temudo MF, Kleerebezem R, van Loosdrecht M. 2007. Influence of the $\mathrm{pH}$ on (open) mixed culture fermentation of glucose: A chemostat study. Biotechnol Bioeng 98:69-79.

Thompson JD, Higgins DG, Gibson TJ. 1994. Clustal-W-Improving the sensitivity of progressive multiple sequence alignment through sequence weighting, position-specific gap penalties and weight matrix choice. Nucleic Acids Res 22:4673-4680.

Walsby AE, Avery A. 1996. Measurement of filamentous cyanobacteria by image analysis. J Microbiol Methods 26:11-20.

Yu ZT, Morrison M. 2004. Comparisons of different hypervariable regions of rrs genes for use in fingerprinting of microbial communities by PCRdenaturing gradient gel electrophoresis. Appl Environ Microbiol 70:4800-4806.

Yu HQ, Mu Y. 2006. Biological hydrogen production in a UASB reactor with granules. II: Reactor performance in 3-year operation. Biotechnol Bioeng 94:988-995.

Zhang ZP, Show KY, Tay JH, Liang DT, Lee DJ, Jiang WJ. 2007. Rapid formation of hydrogen-producing granules in an anaerobic continuous stirred tank reactor induced by acid incubation. Biotechnol Bioeng 96:1040-1050.

Zhang ZP, Adav SS, Show KY, Tay JH, Liang DT, et al. 2008. Characteristics of rapidly formed hydrogen-producing granules and biofilms. Biotechnol Bioeng 101:926-936. 